NABA Tecomical Memorandum 87131

\title{
Experimental Performance of a -Kilowatt Arcjet Thruster
}

Shigeo Naxanishi Lewis Research Center Cleveland, Ohio

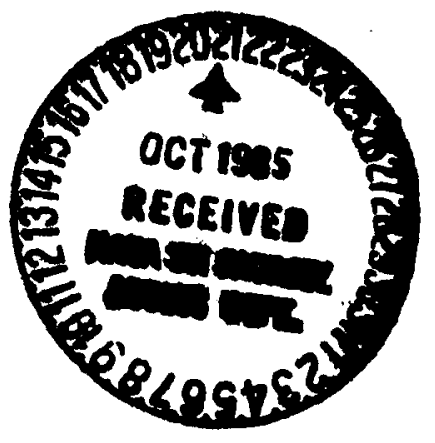

(NASA-TH-87131) EXPERIMENTAL PERFORMANCE OF A 1-KILONATT ARCJET TRRUSTER (NASA) $30 \mathrm{p}$ HC A03/AF A01

CSCL $21 C$

Prepared for the 18th International Electric Propulsion Conference cosponsored thy the AIAA, DGLR, and JSASS Alexandris, Virginia, September 30-October 2, 1985 


\author{
EXPERIMENTAL PERFORMANCE OF A 1-KILONATI ARCJET THKUSTER \\ Shigeo Nakanisht \\ National Aeronautics and Space Administration \\ Lew1s Research Center \\ Cleveland, Ohto 44135
}

\begin{abstract}
SUMMARY
A formerly unused cathode and anode/nozzle assembly from a filght model arcjet has been tested with nitrogen, hydrogen, and nitrogen-hydrogen mixture simulating ammonia decomposition products at arc power levels from about 300 to $950 \mathrm{~W}$. Two different power sources and two nozzle configurations were tested at low background pressures to exclude faclitity effects.

Incireased nozzle expansion ratio improved cold-flow nozzle efficiency from 0.8 to 0.9 . Hydrogen thrust efficlency of 0.26 at 872 sec specific impulse matched some 1964 performance on a similar device. Simulated ammonia thrust effictency was 0.31 at $422 \mathrm{sec}$.

Spontaneously occurring voltage mode rhanges at constant arc current could be partialiy stablilized with appropriate power source characteristics. In the higher voltage mode specific impulse was higher, but thrust efficiency changed only slightly from that of the lower voltage mode. Sustained tests of up to $2 \mathrm{hr}$ duration exhibited no apparent performance degradation with time.
\end{abstract}

\title{
INTRODUCTION
}

During the 1960's, considerable effort was expended by both the industrial and government sectors on arcjet thruster research and technolcay. A comprehenstve survey made in 1965 documented and summarized the state of art at that time (ref. 1). Hydrogen arcjets ranging in power levels from 1 to $200 \mathrm{~kW}$ were investigated. Other propellants like aminonia, lithlum hydride, and methane were used principaliy in low power thrusters.

The general conclusions at that time were: (1) arcjets operating at power levels in the tens of kllowatts were more efficlent and demonstrated longer ilfe potentlal than at low power: (2) electrode life was an unresolved issue al though one $30-k W$ test ran continuousiy for $500 \mathrm{hr}$ (ref. 2), and another test ran for $720 \mathrm{hr}$ with interruptions but with a voluntary termination (ref. 3); (3) lack of sufficlent space electric power and near term mission applications led to temporary abandonment of further research and development.

New space mission requirements have reawakened interest in the arcjet. As a thruster concept. it has the potential of high thrust and power dens, ies, simplicity, and cholces of propellants to suit specific impulse and system requitrements.

The 1-kW arcjet used in this investigation was designed and developed by the plasmadyne Corporation in the early 1960's as a possible candidate experiment in a space electrlc rocket test (ref. 4). Ground tests with hydrogen propellan' demonstrated a thrust efficlency of 25 percent at a specific 
impulse of $1000 \mathrm{sec}$ (ref. 4). Performance degraded with time presumably due to erosion of the anode/nozzle electrode. Using ammonia as propellant, a thrust efficlency of 8 percent at a specific impulse of $550 \mathrm{sec}$ was obtained. For near term auxiliary propulsion applications, ammonia and hydrazine are the favored propellants for storability reasons.

The present investigation seeks to renew and extend the testing and evaluation performed on the 1-kW Plasmadyne flight model thruster. It w1ll estab11sh a baseline performance of a configuration originally designed for a 24-min flight using hydrogen. As part of a continued development program, the basic components of the thruster w111 be tested over a range of power levels and propellant flow rates, primarily with hydrogen and a nitrogen-hydrogen mixture to simulate ammonia decomposition products. Both imposed and spontaneousiy occurring operational behavior will be described.

For this investigation, the basic thruster design was kept intact with only minor changes although the nozzle throat diameter increased and stabilized during the initial tests. Further changes will be motivated and guided by the understanding gained from tests on this already well-developed thruster and by design principles which evolve from these studies.

\section{APPARATUS}

\section{Thruster}

A photograph of the Plasmadyne 1-kW arcjet thruster system is shown in figure 1. In accordance with the filght test program requirements, the system size was limited to $20.3 \mathrm{~cm}$ in diameter, $35.6 \mathrm{~cm}$ length, and a mass of $5.5 \mathrm{~kg}$, or less. It had to be capable of $24 \mathrm{~min}$ of unattended and predictable operation. The liquid hydrogen propellant tank was double-walled and vacuum Jacketed. The round baffle located between the mounting bracket and the thruster nozzle was an insulated reflector shield to minimize rearward heat transfer from the radiatively cooled nozzle. Other design cietalls are described in reference 4.

A partial cross-section view of the cathode-anode/nozzle assembly is shown in figure 2. The cathode was a $3.2 \mathrm{~mm}$ diameter, 2 percent thorlated cungsten rod held concentrically within a $7.8 \mathrm{~mm} 0.0$. molybdenum tube. Enough clearance was provided around the cathoce rod to permit part of the propellant gas flow to regeneratively cool the cathode. The outside surface of the molybdenum tube had a hellcal groove which allowed the remainder of the propellant gas to swirl as it flowed between the tube and its boron nitride housing. The metal ring seals (K-seals) of the original design were modifled to avold propellant gas leakage which increased as repeated disassembly and reassembly progressively deformed the K-seal rings. The periphery of the sealing flange was ground to a contcal surface which seated on a mating boron nitride surface. pressure check indicated the leakage rate to be about $3 \times 10^{-6} \mathrm{~kg} / \mathrm{sec}$ of room temperature nitrogen gas at a presourse differential of $3.8 \times 10^{5} \mathrm{~Pa}$. At normal operating pressures and temperatures the leakage is estimated to be sbout 2.4 percent of the corresponding propellant flow rate.

The anode/nozzle configuration was originally designed for a hydrogen flow rate of $5 \times 10^{-6} \mathrm{~kg} / \mathrm{sec}$ at a nominal arc chamber pressure of $7.6 \times 10^{5} \mathrm{~Pa}$. 
The tungsten nozzle insert had a throat diameter of $0.23 \mathrm{~mm}$ and diverged to $1.27 \mathrm{~mm}$ to give an area ratio of about 30 . The downstream face of the nozzle was flat to benefit from any possible thrust generated by the kinetic energy of gas molecules leaving the surface. The length and outside diameter of the molybdenum nozzle was sized to accomodate radiant cooling.

For the tests at the Lewts Research Center, the cathode/anode/nozzle assembly was remoced from the flight system and mounted on a thrust platfr:m as shown in figure 3. Early tests with this installation encountered sev-ral

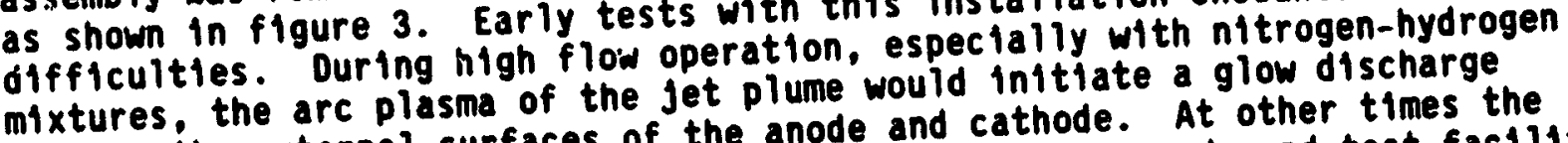
between the external surfaces of the anode and cathode. anode and test facli1ty walls, and bare electrical leads. Thesedem from facility ground, (2) enclosing (1) electrically isolating the power syste housing, and (3) covering all elecInasmuch as two nozzle configurations were trical leads with insulation. Inasmuch as two destgnated "short nozzle." As the throat diameter enlarged due to erosion, a boron nitride extension was used to provide a larger nozzle expansion ratio and to expand the nozzle contour to the outside diameter of the molybdenum body. Figure 2 shows this extension for which the nozzle coordinates were obtained from reference 5 . The extension was strapped to the molybdenum body with two tantalum bands which were held in tandem but could be tightened independently. Using this approach, different nozzle configurations could be tested without altering the original anode/nozzle geometry. The second configuration with the boron nitride extension will be designated "extended nozzle."

\section{Power System}

Two types of power system were used in the investigation. The first type was the conventional dc power supply-ballast resistor combination. The $440 \mathrm{~V}$, 3 phase, ac to dc power supply was rated for an output oflc crossover. The trollable in elther voltage or current mode with autent was verified to be manufacturer's specifications of
$0.8 \mathrm{~V}$ plus 0.4 percent of the output voltage.

The ballast resistor consisted of four $3 \&$ rheostats connected in series with a rated current of 12.9 A with continuous alr cooling. Although of undetermined benefit, a $1.0 \mathrm{mH}$ inductor was included in the circult to make the series R-L.C.C circult overdamped.

Most of the testing was performed with the conventional power system. Some tests were also performed with a $10 \mathrm{kHz}$ pulse-width modulated solid state power processor designed and bullt at the Lew1s Research Center (ref. 6). No ballast resistor was required and the power processor operated at greater than 90 percent effictency.

\section{Instrumentation}

Thrust measurement. - The thrust measurement system consisted of a 12.7 by $22.9 \mathrm{~cm}$ platform upon which the arcjet thruster was mounted using appropriate thermal 1solation. The platform itself was supported on four flexure 
springs made of 1.27 by $4.3 \times 0.023 \mathrm{~cm}$ thick machined stainiess steel. The motion of the platform due to appiled thrust was transmitted mechanically to a strain gage force transducer. The transducer was rated for a force of $1.47 \mathrm{~N}$ full scale so that the resisting force against the applied thrust was due to both the flexure springs and the force transducer. Thrust stands of the same deitgn have been used extensively in resistojet testing (ref. 7 ).

The mechanical pumps of the two vacuum facilities operating in the same bullding, caused an unacceptable amount of vibration in the thrust platform. It was necessary to incorporate a pair of friction-free viscous dampers filled with low vapor pressure diffusion pump fluld. The signal output from the force transducer was of the order of $0.10 \mathrm{~V}$ with $5 \mathrm{~V}$ dc excitation across 1ts strain gauge bridge. For recording on the multi-channel recorder, the output signal was filtered with an active notch filter set between $6 \mathrm{~Hz}$ low pass and $100 \mathrm{~Hz}$ high pass. The flitered signal was then fed to a variable gain differential dc amplifier so that the recorder output could be calibrated to read directly in conventent engineering units.

Calibration was performed by successively applying or removing $4 \mathrm{gm}$ lead weights attached to a windlass via a monofilament thread. By using three such weights, the thrust measurement system was calibrated from 0 to $0.118 \mathrm{~N}$ with a recorded resolution of $4.9 \times 10^{-4} \mathrm{~N}$ in the $0.049 \mathrm{~N}$ full scale range to $2.5 \times 10^{-3} \mathrm{~N}$ in the $0.245 \mathrm{~N}$ full scale range. True accuracy under dynamic loading has not beell established, but static error was less than \pm 1 percent of full scale with linearity within 0.8 percent up to $0.12 \mathrm{~N}$.

The greatest difficulty encountered was drift of the zero point during long tests because of thermal input to the thrust measurement system. As mentioned previousiy, the thruster was mounted on the thrust platform using two thermally isolated mounts. The aluminum base of the thrust stand was watercooled with a copper coll imbedded in a milled groove. In addition, a water cooled copper enclosure was placed over the entire thrust stand with only the thermally isolated thruster mounts protruding. During long tests of $1 \mathrm{hr}$ or more a small zero drift was still present, but thrust zero was established perlodicaliy by a method described under Procedure. In-situ calibration during thruster operation was performed to verify the load increment accuracy of thrust measurement in spite of the zero point drift.

Power metering. - Arc power was obtained by measuring the arcjet voltage and current at the elertric:l feed-through terminals outside the vacuum faci1ity. The current sensor was a calibrated shunt rated for $100 \mathrm{mV}$ output at $20 \mathrm{~A}$ in the line to the cathode. The output signal was amplified through a differential input dc ampliffer before golng to a signal isolation system. The arc voltage signal was divided to a sultable level before isolation.

In order to operate the arcjet electrically isolated from faclitity ground without exceeding the common mode isolation $11 \mathrm{mit}$ of the multi-channel recorder, the arc voltage and current signals were sent to a pair of transformercoupled isolation amplifiers. The entire system was calibrated by applying known signals at the feed-through terminals.

Flow metering. - The flow control and metering system was designed to use selectively gases such as argon, nitrogen, hydrogen, and nitrogen-hydrogen 
mixtures. Three separate gas inlet lines were cross-connected and valved with bellows-sealed shut off vaives to eliminate leakage.

The flow meters were commerclally avallable thermal conductivity element

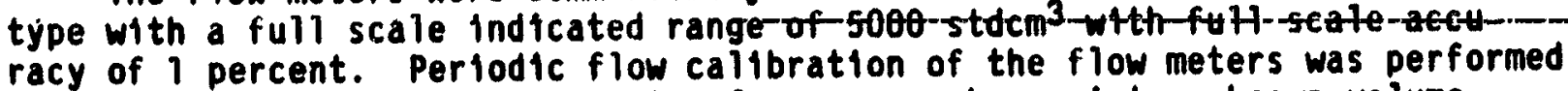
in-situ by measuring the time rate of pressure change into a known volume. flow adjustment was performed with a micrometer screw type leak valve, also with bellow seals. A final valve after the flow adjustment and mixing points convenientiy allowed shut-off and turn-on without readjustment of the flow rates of a single gas or mixture of gases.

Arcjet chamber pressure measurement was 11 mited to the gas 'eed 11 ne pressure at the vacuum feed-through flange. The pressure drop in the feed line between the point of measurement and the arcjet was determined by measuring the feed line pressure as a function of flow rate with the line disconnected at the arcjet and exhausting to atmosphere. The maximum pressure drop was about $2.9 \times 10^{4} \mathrm{~Pa}$ at $5000 \mathrm{stdcm}^{3}$ of nitrogen, and much less for other gases.

Data recording. - Simultaneous recording of up to eight variables was accomplished by means of a multi-channel direct inking strif chart recorder. Each channel had fixed gain or varlable gain adjustments and chart speeds up to $200 \mathrm{~mm} / \mathrm{sec}$. For most of the arcjet operation a recording speed of $1 \mathrm{~mm} / \mathrm{sec}$ was used. The following table shows the recorded varlables and their full scale readings.

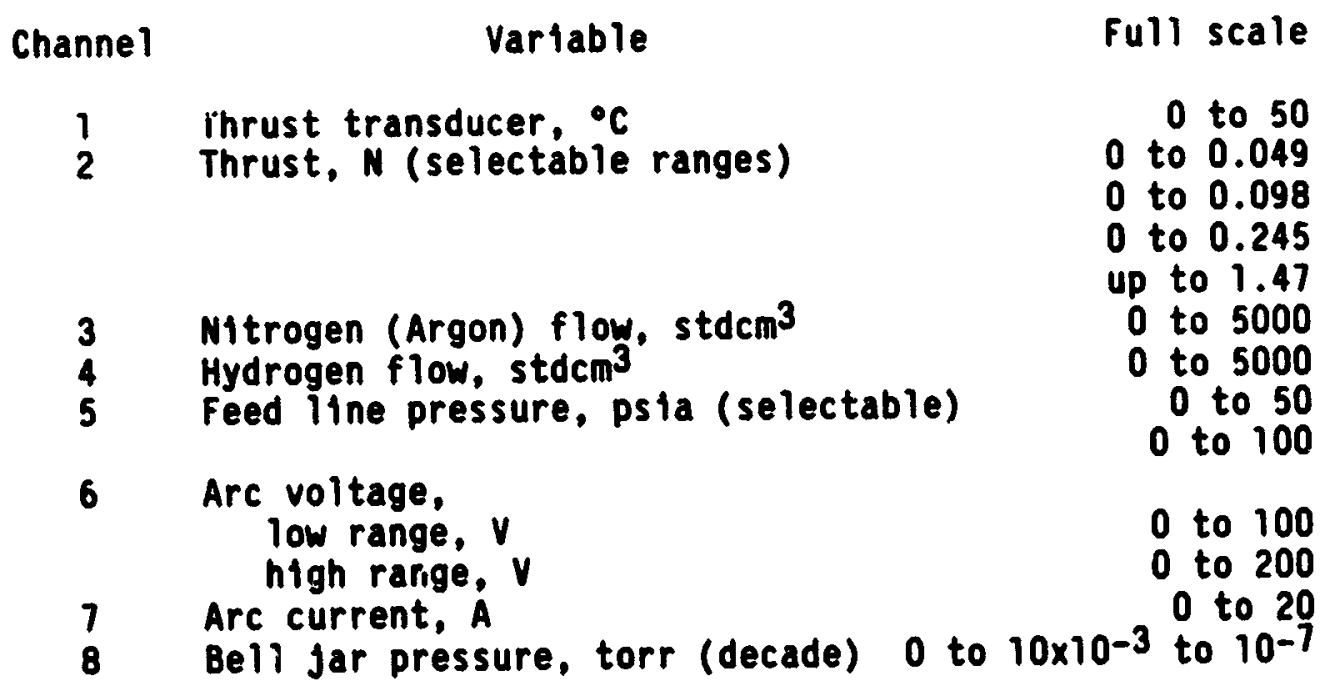

\section{Vacuum Fac1lity}

The vacuum faclilty used for the tests was a 1.5 bj $5 \mathrm{~m}$ long chamber with sour $82 \mathrm{~cm}$ dlameter 011 diffusion pumps and a rotary blower backed by a mechanical roughing pump. The rated pumping capacity of each diffusion pump was 15000 ifters/min at 10-4 torr. For conventence and economy, tap water was used in the diffusion pump cold traps instead of liquid nitrogen.

As shown in figure 3 , the thruster was installed in a $0.9 \mathrm{~m}$ diameter by $0.8 \mathrm{~m}$ cylindrical test section which could be isolated from the vacuum faclitty 
by closing a $0.9 \mathrm{~m}$ diameter gate value. Actual pumping performance in the test section was about $3 \times 10^{-4}$ torr at a nitrogen flow rate of $19.7 \times 10^{-6} \mathrm{~kg} / \mathrm{sec}$ and $5 \times 10^{-3}$ torr at $99 \times 10^{-6} \mathrm{~kg} / \mathrm{sec}$. Thrust measurements were restricted to thruster oparation with test section pressures no greater than $1 \times 10^{-3}$ torr to minimize its effects on nozzle performance. The effects of background pressure were determined for each nozzle configuration by measuring the thrust from a constant flow rate of room temperature gas while varying test facility pressure.

\section{PROCEDURE}

Test procedure included those which were routinely followed regardless of test type and others which were specific to a given test. Prior to any test, after temperature equilibrium was obtained, the thrust measurement system was callibrated. The signal output with each calibration weight was recorded on the strip chart to perform a total system calibration. With the arcjet at room temperature, a cold-flow (room temperature gas) calibration was then performed for each gas or mixture of gases over the flow range normally used in thruster operation. Recorded variables for cold flow were thrust, gas flow rates, feed-line pressure, and bell jar pressure.

The arcjet was ignited by throttling the final shut-off valve in the flow metering system causing the pressure in the arc chamber to drop. At whatever pressure was required for a Pasehen breakdown with an applied 400 to $600 \mathrm{~V}$, the arc current would suddenly jump to the controlled value set in the power supply output. The shut-off valve was then immediately opened to obtain the pre-set gas fiow rate and steady arc operation at the selected arc current.

Accurate performance measurements required several minutes of steady-state operation to obtain equilibrium conditions depending upon the type of input variable change. This introduced the possibilities of long-term thermal drift in the thrust system zero reading. Particularly in long tests, it was necessary to reestablish the zero point perlodically by shutting off the arc and the gas flow to obtain a known zero thrust condition.

\section{RESULTS AND DISCUSSION}

The initial part of this section will discuss arcjet operation and characterfstics which were common to both nozzle configurations tested. Included in the discussion are the voltage-current characteristics of the arc and typical load lines for the two types of power sources used to operate the arcjet.

In order to characterize nozzle performance apart from arc operation, the short and extended nozzle configurations were tested under cold flow cond 1 tions. Operational arcjet, or hot flow, performance of the two configurations are then presented. Finaliy, the improved performance obtained with the extended nozzle configuration in a sustained test with a nitrogen-hydrogen mixture w111 be shown.

The terms and definitions used throughout the report are given in append1 $\mathrm{A}$. 
With initial short runs of famlifarization, the arcjet could be started arid operated rellabiy. Each post-run examination showed the nozzle throat to be eroding more rapidiy than anticipated. Within an accumulated run time of less than $1 \mathrm{hr}$, the origlially $0.23 \mathrm{~mm}$ dlameter nozzle throat enlarged to $0.76 \mathrm{~mm}$. The throat diameter stab111zed at the latter value, and all performance data reported herein were obtained with the larger throat. Perlodic gage measurements showed no apparent increase in throat diameter except for noncircular irregularities vistble in the photomicrograph shown in figure 4. These irregularities did not change appreclably with accumulated run time which was in excess of $20 \mathrm{hr}$ at the time of the photograph. A further enlargement of the photograph was used to determine the cross-sectional area, which was found to be $4.623 \times 10^{-7} \mathrm{~m}^{2}$, or 1.4 percent greater than the c1rcular area of a $0.76 \mathrm{~mm}$ diameter hoie. Also visible in the photograph are small globules of molten metal which are belleved to be from the throat and nozzle wall 1 mmediately downstream of the minimum area section where the arc struck. The nozzle throat region was almost always white hot, and anode meiting was probable during operation with the arc seated in this vicinity.

Component tests have been conducted on constricted arcs and their results are reported in companion papers. Mass loss in radiation-cooled anodes was found to decrease with increased gas flow rate (ref. 8). In vortex-stabilized constricted arcs with water cooled anodes, erosion was found to be minimal (ref. 9). These results tend to indicate that the constrictor and nozzle throat aire regions of extremely high temperatures which must be controlled or limited to minimize erosion.

Starting. - As mentioned in Procedure, the arcjet was usually ignited by initlating a low pressure gaseous breakdown. It was also possible to start at full gas pressure by moving the cathode to draw an arc, or sometimes simply by applying $400 \mathrm{~V}$ to the anode.

Startup was usually easy and smooth with argon, while hydrogen and nitrogen-hydrogen mixtures were often harder to start. In extreme cases, when voltages up to $600 \mathrm{~V}$ were required, a less stressful method of starting with argon and changing over to other gases was used. No clear reason for difficult starting has been identifled, and definitive tests are better reserved for a final configuration in which performance and iffe requirements have also been integrated into the design.

Mode change instab1lity. - At least two major recognizable modes of arcjet operation have been observed. While the arc current and all other parameters such as propelled flow rate and background pressure were held constant, the arc voltage was observed to shift from a low to higher voltage mode, operate in that mode for a perlod of time and then drop back to the lower voltage mode. These mode changes were accompanled by the appearance or disappearance of a visible plume downstream of the nozzle. The plume was highly visible in argor, when operating in the high voltage mode. With $\mathrm{H}_{2}$ and $\mathrm{N}_{2}-\mathrm{H}_{2}$ mixtures, the plume was much less luminous but still visible under subdued lighting conditions. In the low voltage mode, the plume would disappear although a bright discharge was st111 visibie upstream of the nozzle throat. observations indicated that the low voltage mode corresponded to anode arc attachment upstream of the nozzle throat and downstream attachment in the 
higher voltage mode. The flow region downstream of the throat, being a region of decreasing pressure, was also characterized by a diffuse arc attachment to the anode. Later discussion will show that the mode change instability could be alleviated with proper power controller characteristics.

\section{Voltage - Current Characteristics}

The relationship between arc voltage and current is shown in figure 5 . The data include two propellant gases over a range of propellant flow rates, and typical load lines for the ballasted and the pulse width modulated power sources. In all cases, the arc voltage decreased with incieasing current which is characteristic of high current arcs. The curves for hydrogen show the low and high voltage modes of operation at the same propellant flow. For a given mode, the arc voltage generally increased with flow rate. The arc extinction 1 imits for all the cases shown were between 4 and $5 \mathrm{~A}$ regardless of arc power which varled from about 269 to $600 \mathrm{~W}$ before extinction depending upon voltage mode and propellant type.

The arc characteristics with the nitrogen-hydrogen mixture, when operated with the modulated power source, were also examined. The controllable current range was narrow because of the output characteristics of the modulated source. The voltage-current characteristics of the arc were found to be similar for both power sources when operating in the same arc voltage mode.

Superimposed on the arc characteristics are the output load characteristics of the two power sources. The higher ballast resistance resulted in. a steeper load line but also in higher power dissipation.

The pulse width modulated power source improved the arc current regulation without incurring the large power dissipation. Its output characteristics for a range of load resistance at a flxed current control setting are shown in figure 5. Other values of current setting would generate a family of curves displaced to either side of the one shown. The steepness of the output curve implies a very tight current regulation and should be helpful in maintaining constant arc current during rapid changes in effective arc resistance.

The changes in arc voltage mode are belleved to be assoclated with movements of the attachment point and corresponding changes in arc voltage drop. Sometimes the mode change could be intentionalily produced by changes in gas flow rate, arc current, or both. At other times, the mode change could occur spontaneously with no perceptible change in the externally controlled operating parameters. An example of arcjet behavior with the two types of power source is shown in figure 6 . Reproductions of the strip chart recording of. the-var1ous signals are shown with their nomenclature and full scale values.

F1gure 6(a) 1llustrates an arcjet mode change from 76 to $52 \mathrm{~V}$ whlle operated "with" a bailasted power source at $10 \mathrm{~A}$ arc current using hydrogen prope 1lant. The arc current trace appeared nolsy. but the very fast and large current spikes might have been EMI induced $n$; affecting the instrumentation. Attempts to restore the higher voltage mode by stopping and restarting were unsuccessful. A quick change to the modulated supply and a restart obtalned the quiet, higher mode operation shown in figure $6(b)$ at essentially tie same arc voltage as with the ballasted supply. Continued operating at constant conditions began to encounter short downward excursions in voltage, but each 
time the voltage returned and remained in the higher mode. It is belleved that the ballasted system would have allowed drop-off into the lawer mode without regalning the higher mode operation.

\section{Thruster Performance}

Because of the rapld initial erosion of the nozzle throat, meaningful performance data with hydrogen intended for the original configuration were not obtained. After the throat size stabilized. the thruster was operated with hydrogen, nitrogen, and a $\mathrm{N}_{2}+3 \mathrm{H}_{2}$ mixture simulating ammonia decomposition products.

Cold flow. - Cold flow data with room temperature gases were obtained with each configuration to evaluate nozzle performance exclusive of heat addition and unknown gas composition effects. These effects undoubtediy change nozzle performance, but if the nozzle thrust coefficlent is assumed nearly constant, the ratio of nozzle inlet pressures between hot and cold flow conditions, to first order. Is an indication of the thrust ratio, and hence specific impulse. With the short nozzle, cold flow tests with and without the cathode wern made. The purpose for removing the cathode was to obtain nozzle performa!nse without the large internal pressure drop and the posstble effects of the cathode tip located close to the nozzle throat.

Cold flow thrust measurements with different gases were found to be linear functions of mass flow rate as expected for a constant gas temperatures. The cold specific impiulse for each' gas was, therefore, also constant-over the.flow range. The theoretical specific impulse, Isp. (eq. (AI)) for each gas can be used to define nozzle efficlency as a ratio of measured to theoretical specific impulse.

The nozzle efficlency for the short nozzle with cathode, short nozzle without cathode, and extended nozzle with cathode is shown in figure 7 . For all three cases, the nozzle efficlency was highest with nitrogen, intermediate with the nitrogen-hydrogen mixture, and lowest with hydrogen. Of the two pure gases for which gas properties are known, nitrogen was operating at a Reynolds number, based on the throat diameter, of 1370 to 5500 . The Reynolds number in hydrogen was 400 to 1400 . These values were based on gas viscocittes near room temperature. At higher gas temperatures the Reynolds number would be lower. The effects of having the cathode present were relatively minor but were most noticeable with hydrogen. A more significant effect on nozzle efficlency was due to the increased expansion ratio of the extended nozzie. Comparing the short and extended nozzle configurations with cathode in place, the nozzle effictency increased approximately 0.10 for all three gases. Using one-dimensional isentropic flow relationships, the ratio of exit velocities, hence specific impulses, of nozzles with different expansion ratios can be shown to vary inversely as the expansion ratios and inversely as the nozzle exit pressure raised to the power, $1 / k$, where $k$ equals the specific heat ratio of the gas flowing at constant inlet temperature and mass rate. The exit pressure in the extended nozzle was assumed equal to the facility background pressure. In the short nozzle, the effective area over which the true exit pressure extended is not clear. Because of nozzle throst erosion. the expansion ratio was about 2.78. Neglecting the exit pressure effect upon the underexpanded nozzle exit area, the extended nozzle with an expansion ratio of 2300 could result in an exit velocity, or specific impulse, about 30 percent 
greater. In practice, the specific impulse was only 10 percent greater. The effects of the flow fleld in the exit plane of the short nozzle are undetermined, but one-dimensional flow theory does imply the possibility of the observed increase in nozzle performance. It is interesting to note that for the extended nozzle, the nozzle exit pressure after isentrapic expansion was calculated to be $3 \times 10^{-6}$ times the nozzle inlet pressure. A representative inlet pressure obtained with cathode removed was $7 \times 10^{4} \mathrm{~Pa}$ at a nitrogen flow rate of $60 \times 10^{-6} \mathrm{~kg} / \mathrm{sec}$. The calculated nozzle exit pressure would be $0.21 \mathrm{~Pa}$, or $1.6 \times 10^{-3}$ torr. The test facll1ty background pressure at this nitrogen flow rate was $9 \times 10^{-4}$ torr as measured by an tonization gage.

The feed line pressure for each gas for the short nozzle configuration is shown in figure 8 . Actually, pressure in the arc chamber just ahead of the nozzle would be of greater interest, but there was no conventent way to measure this pressure. The regenerative flow design of the cathode will be shown to cause considerable pressure drop in addition to the ilne drop between the point of pressure measurement and the thruster connector. The data in figure 8 show considerable departure from the linear relationship suggested by onedimensional choked flow calculations, and a different minimum area would be inferred for each gas. The reasons for these discrepancles are not clear, but the well-behaved linearity in the thrust measurement independent of pressure indicated that a better measurement of nozzle inlet pressure was needed. In all cases, the calculated throat area was smaller than the circular area of a $0.76 \mathrm{~mm}$ diameter hole. To obtain a larger calculated area, the pressure should be lower. which would be the case if pressure drop occirred between the point of measurement and the nozzle inlet.

The measured pressure with the cathode removed is shown in figure $8(b)$. In comparison, the feed pressure without the cathode was approximately 0.5 to 0.6 of the pressure with cathode in place (fig. $8(a))$. The resulting calculated throat areas were correspondingly larger but still less than the physical area.

The measured thrust and nozzle parameters for the short nozzle configuration with the cathode removed are shown in figure 9. Th1s was the only configuration for which measured feed line pressures closely approximated nozzle inlet pressures. The measured thrust shown in figure 9 (a) was linear with pressure and almost formed a single 11 ne for all gases. The pressure-thrust relationship can be expressed as, $F=C_{F} A^{*} P$, where $C_{F}, A^{*}$, and $P$ are the thrust coefficlent. throat area, and nozzle pressure, respectively. If the thrust coefficient were constant over the pressure range, thrust would be linear with pressure.

Dividing the measured thrust by the measured pressure yields the parameter, $C_{F} A^{*}$. shown in figure $9(b)$. Assuming an area of $4.56 \times 10^{-7} \mathrm{~m}^{2}$ for a $0.76 \mathrm{~mm}$ diameter throat, the thrust coefficlent shown in figure $9(b)$ is representable by a curve that is characteristically flat at the high pressure end and droops with decreasing pressure. As an upper $11 \mathrm{mit}$, the theoretical thrust coefficlent is indicated. The value of 1.8 corresponds to a fully expanded nozzle operating at a large pressure ratio with a perfect gas having a specific heat rat10 of 1.4. Departure of the asymptotic value from the ideal is believed to be due to the viscous flow effects of a small nozzle at low Reynolds number. 
Hat flaw. - The short nozzle configuration was tested with hydrogen and $\mathrm{N}_{2}+3 \mathrm{H}_{2} \mathrm{mix}$ tures over a range of arc discharge power. The perforinance in terms of thrust effictericy and specific impulse is shown in figure 10. The lower bound of efflclency with hydrogen was 0.10 . simllar to some plasmadyne data obtalned $20 \mathrm{yr}$ ago. Their test reports did not fully explain the causes of performance varlations other than thrust measurement uncertalnties and noz27 e throat erosion of 11 to 14 percent along different dlameters. A broader range of thrust efficlency was obcalned at that time, the maximum being about. 0.27 compared with 0.175 recentily. The early specific impulse was approxi. mately twice as high, primarlly berause the arc power level was more than double that of recent tests. Based on input power and mass flow rate, the specif lic energy input for the Plasmadyne data was about $2.5 \times 10^{8} \mathrm{~J} / \mathrm{kg}$ compared with about $7 \times 10^{7} \mathrm{~J} / \mathrm{kg}$ in the recent tests.

With the $\mathrm{N}_{2}+3 \mathrm{H}_{2} \mathrm{mixt}$ ire, the efficlency ranged from 0.07 to 0.12 . A single reported value by Plasmadyne for ammonia gave a spectfic impulse of $550 \mathrm{sec}$ at an efficlency of 0.08 for $920 \mathrm{~W}$ of arc power. It should be noted that the thrust $\varepsilon f f i c l e n c l e s$ obtained with the nitrogen.hydrogen mixture have not been corrected for the dissoclation energy inherent with ammonia. Unless this energy is recovered by regenerative cooling or recombination, the efficlency would be lower. The energy input, Plasmadyne's ammonla test was $1.8 \times 10^{8} \mathrm{~J} / \mathrm{kg}$ compared with $3 \times 10^{7} \mathrm{~J} / \mathrm{kg}$ for the nitrogen-hydrogen mixture.

Performance of the extended nozzle configuration operated in varlous gases and with normal and reversed polaritles is shown in figure 11 . Reversed polarity operation denoted by the solid symbols was obtained by reversing the external power lead connections so that the normaliy cathode electrode was positive with respect to the nozzle/anode. The data points cover a range of propellant flow rates and arc power. Thrust efflciency ranged between 0.15 to 0.30 over a specific impulse range of 200 to $900 \mathrm{sec}$. Maximum efficiency and specific impulse obtairied with hydrogen were 0.26 at $872 \mathrm{sec}$; with nitrogen, 0.23 at $220 \mathrm{sec}$; and with the nitrogen-hydrogen mixture, 0.31 at $422 \mathrm{sec}$.

The reversed polarity operation gave slightly higher efficiency with hydrogen at the high end of the I sp range. Within the scatter of the data, however, nelther polarity showed a clear superfority.

The thrust to power ratio shown in figure $11(b)$ varled from about. 0.22 to $0.05 \mathrm{~N} / \mathrm{kW}$, decreasing with increasing speciftc impulse for propellants with lower molecular welghts.

\section{Mitrogen-Hydrogen Mixture Test}

Prevlous tests had been run at essentlally constant propellant flow ratcs. These tests were made with the ballasted power supply, and changes in thruster operation included both intentional and spontaneous vartations in arc power.

Two separate tests of different duration using a $1: 3 \mathrm{mixt}$ re of nitrogen and hydrogen were mad. with the pulse width modulated power processor at essen tlally constant curreni. The processor tended to maintain the higher voltage mode operation more consistently, although short perlods of the lower mode operation did occur. Intentional periodic shutdowns were also included to re establish the thrust stand zero. 
A time plat of a 2-hr test 1 s shown in tigure 1\%. The total run time had three phases shown by data points interconnected by dotted lines to indicate the sequence, not to infer a functional rclationship with time.

The first phase was a startup and stabilizing perlod during which the arc current was controlled to a mean value of $B A$ with a random variation of

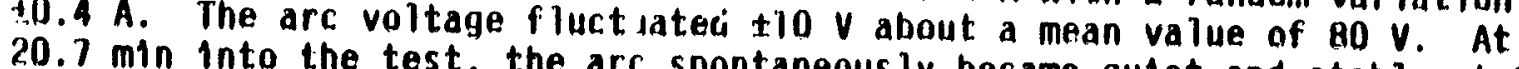
and $8.8 \mathrm{~A}$.

The second phase of the test was at essentially constant power with a shutdown and thrust zero reading at 33,63, and 91 min into the test. Sevcral spontaneous changes to the lower voltage mode occurred during this phase. The first change occurred $29.3 \mathrm{~min}$ into the test w1th the arc voliage dropping to $74 \mathrm{~V}$ at $9 \mathrm{~A}$. The arc persisted in this mode for 3 min at which time the propellant flow rate was increased to $31 \times 10^{-6} \mathrm{~kg} / \mathrm{sec}$. The increased flow rate helped the arc to resurie the high 01 tage mode at $86 \mathrm{~V}$ and $10 \mathrm{~A}$.

Following the first intentional shutdown and restart, the ar $r$ dined the low mode for $36 \mathrm{sec}$ before transition to the high mode. It sustiined:? mode continuously for $26 \mathrm{~min}$ unt1l a low mode change lasting 40 sec occ:! then regained the high mode before shutdown at $63 \mathrm{~min}$. The secu, " $r$ " began in the low voltage mode which persisted for 3 min hef: "ansic... to to the high mode. Prior to the third shutdown at $92 \mathrm{mill}$. cest. one mode change occurred which lasted about 2 min before re $\cdots$, ig to high mode.

The final test phase lasting $30 \mathrm{~min}$ was at various propellant flow rates and nearly constant arc current of 9.2 to $10 \mathrm{~A}$.

The range of $\mathrm{N}_{2}+3 \mathrm{H}_{2}$ propellant flow rate is snown in figure 12(a). The flow rate was licreased slightly for the second phase of the test and the variations that occurred during that period were due to drift. The final phase of the test took the flow rate to a maximum value allowable while maintaining the test facility pressure in the low $10^{-3}$ torr ranges. Allowing sufficlent time for the flow and thruster operation to stabilize, the flow rate was incrementally reduced until the arc became fluctuating and unstable.

The varlations in arc power shown in figure $12(b)$ were due to vartations in arc voltage because the current was essentially constant. Increased flow tended to increase the arc voltage provided the arc remained in the high voltage mode. This trend was espectally noticeable in the third phase when a decreasing propellant flow rate caused a lowering of the arc voltage, hence
arc power.

The speciftc impulse shown in figure $12(\mathrm{c})$ reached $400 \mathrm{sec}$ and held constant for most of the second phase. The initial increase in $I_{s p}$ occurred when the arc power was increased from 264 to $666 \mathrm{~W}$. The corrasponding increase in I sp from 210 to $314 \mathrm{sec}$ resulted in a 50 percent increase in Isp for
a 152 -percent increase in power.

The second Jump in specific impulse was 20 percent for a 26.5 percent increase in power with a noticeatle increase in effictency. (fig. 12(d)). 
During the third phase of the test, the specific impulse was essentially constant despite.... reduction in arc power. The propellant flow rate was being reduced, and the constant $I_{\text {sp }}$ indicated that the gas temperature was remaining essentially constant.

The feed line pressure during the changes in propellant flow rate varled from 19.3 to $27.6 \times 10^{4} \mathrm{~Pa}$. Thermodynamic properties of ammonia at $20.3 \times 10^{4} \mathrm{~Pa}$ show that for an equilibrium gas temperature of $3000 \mathrm{~K}$. ammonia would be almost totally dissoclated, the constituent gases being primarily $\mathrm{H}_{2}$ and $\mathrm{H}_{2}$ with only a mole fraction of 0.01 as monoatomic hydrogen (ref. 10). The theoretical molecular weight of this mixture is 8.125 . The theoretical specific impulse for this inixture is $473 \mathrm{sec}$. A nozzle effictency of 0.87 would lower the specific impulse to $411 \mathrm{sec}$, which is very nearly what was obtained experimentally. The equilibrium specific enthalpy increased from $1.4 \times 10^{7} \mathrm{~J} / \mathrm{kg}$ at 3000 $\mathrm{K}$ to $3.75 \times 10^{7} \mathrm{~J} / \mathrm{kg}$ at $4000 \mathrm{~K}$. Betweell these two temperatures, the mole fraction of monoatomic hydrogen increases from 0.091 to 0.567 . Under equilibrium flow conditions the changes in gas enthalpy should be recoverable as kinetic energy, and hence specific impulse. The fact that much less than one-half the fractional energy change in the arc manifested itseif in specific impulse change indicates that the gas temperature was approaching a level wherein hydrogen dissoctation increased but the energy of dissociation was lost in frozen flow. The pressure range noted above was propellant feed line pressure. The arc chamber pressure was considerably lower which would hasten the onset of hydrogen dissociation and the corresponding frozen flow losses.

The thrust efficiency obtained throughout the test is shown in figure 12(d). After operation stabilized, the efficlency was nominally 0.3 over a test time of more than an hour. During the final phase when propellant flow was reduced, the efficlency also dropped. The relatively small change in arc power of $150 \mathrm{~W}$ over $10 \mathrm{~min}$ allowed sufficlent time for nozzle temperatures to stabilize from point to point as flow was decreased. With constant specific impulse, reductions in propellant mass flow would lower the efficiency as shown by equation (A3). Phenomenologically, these trends might indicate increased frozen flow losses at the lower arc chamber pressures, or poorer energy transfer to the gas and higher wall losses. At the lowest feed line pressure of $19 \times 10^{4} \mathrm{~Pa}$, the nozzle thrust coefficlent was believed to be in the asymptotic region, hence gas expansion was at essentially constant nozzle effictency.

The previously described test used a slightly atypical starting sequence which might have resulted in a relatively long starting transient. A second test lasting $31 \mathrm{~min}$ was run to compare the transient behavior of a iyp $1:$ al starting sequence, also using the modulated power source. Time plots of the same variabies are shown in figure 13. The flow rate of nitrogen-hydrogen mixture was set at $31.07 \times 10^{-6} \mathrm{~kg} / \mathrm{sec}$ from the beginning of test as shown in figure 13(a). A momentary throttling was used initialiy to obtain ignition as described under Procedure and immedlately brought up to rated flow. As shown in figure 13(b), the arc power soon after start was $696 \mathrm{~W}$ corresponding to $69.6 \mathrm{~V}$ at $10 \mathrm{~A}$, the arc current maintained throughout the test. Approximately $2 \mathrm{~min}$ into the test the arc power jumped to $930 \mathrm{~W}$, or $93 \mathrm{~V}$ at $10 \mathrm{~A}$, corresponding to the high voltage arc mode. 
Over the ensuing $12 \mathrm{~min}$, the arc power was essentially constant. Minor variations were due to small changes in arc voltage as the arc chamber increased in temperature and gas pressure. At $14 \mathrm{~min}$ into the test a spontaneous change to the low mode occurred which lasted for $42 \mathrm{sec}$ before reverting to the previous high mode. For tine remainder of the test the arc power, hence voltage, drifted downward silghtly to $900 \mathrm{~W}$. Two short perlods of low mode operation lasting 66 and 3 sec occurred before intentional shutdown at $32 \mathrm{~min}$.

The specific impulse shown in figure 13(c) reflected the variations in power. Immediately after start, the specific impulse was about $333 \mathrm{sec}$ and increased to over 400 sec with increasing arc power and with thruster temperature. The mode change caused a momentary drop but not to the starting level because of the higher arc power and temperature. At the end of the test, the specific impulse immediately after arc extinction was $283 \mathrm{sec}$ which was within $20 \mathrm{sec}$ of the specific impulse at the three intentional shutdowns of the previously described longer test (fig. 12). The cold gas specific impulse evaluated before start of test was $132 \mathrm{sec}$. The difference of $151 \mathrm{sec}$ is attributed to gas heating from the hot wall surfaces.

The thrust efficiency variation during this short test is shown in figure $13(d)$. During the initial $2 \mathrm{~min}$ of the test before mode change, the efficlency increased from 0.21 to 0.26 . At the voltage mode change, the efficlency increased to 0.27 and continued to increase as the thruster approached equilibrium operating temperatures. A silight drop in efficiency occurred when the arc dropped momentarily into the low voltage mode. Two subsequent changes to the low mode resulted in small increases in thrust efficlency. By the end of the $32 \mathrm{~min}$ test, the efficiency was stabilized at about 0.30 .

\section{CONCLUDING REMARKS}

A nominal $1 \mathrm{kH}$ arcjet thruster designed and developed by the Plasmadyne Corporation in the 1960 's has been tested at the Lewis Research Center over a range of arc power from about 300 to $950 \mathrm{~W}$ using varfous propellants. The internal design of the thruster was kept essentially the same as the original. Two nozzle configurations having greatly different expansion ratios were tested. The tests established a data base of currently sttainable performance and showed several aspects of arcjet operational behavior. A pulse-width modulated power source permitted controlled operation over sustained periods of time including intentional shutdown, restarts, and spontaneous transitions into and out of changes in arc voltage modes.

Thrust measurements of known and reproducible accuracy have been used to calculate thruster performance. Maximum thrust effictency and speciffc impulse obtained with hydrogen were 0.26 at 872 sec; with nitrogen 0.23 at 220 sec; and with a $1: 3 \mathrm{mixture}$ of nitrogen and hydrogen, 0.31 at $422 \mathrm{sec}$.

The nozzle conftguration with an expansion ratio of 2300 was found to obtain up to 0.9 of the theoretical specific impulse when operating with equi11 brium gas at room temperature. The gas flow during arcjet operation was probably nonequilibrium, and frozen-flow and viscous losses can be expected to reduce nozzle efficlency. Test factilty pressures maintained below 
$1 \times 10^{-3}$ corr mintmized background pressure effects upon the nozzle and more fully utlilized the high expansion ratio.

Sustained tests of up to 2-hr duration exhibited no apparent performance degradation with time. Other issues like 11fetime starting transients, and operation with propeliants such as hydrazine are not clearly defined at this time. These and other issues related to a complete arcjet filght propulsion system are currentiy being addressed. 
APPENDIX A

Arcjet Performance

The conventional symbols and equations used in evaluating arcjet performance are set forth herein for convenience with a minimum of explanatory detail 11 .

A* nozzle throat area, $\mathrm{m}^{2}$

$C_{F}$ thrust coefficient

F thrust, newton

g gravitational acceleration, $9.8 \mathrm{~m} / \mathrm{sec}^{2}$

$h, c$ subscripts denoting hot and cold conditions

Isp specific impulse, sec

Isp theoretical specific impulse, sec

$$
=\frac{1}{g} \sqrt{\frac{2 k}{k-1} R T_{0}}=C \sqrt{\frac{T_{0}}{M . W .}}
$$

(AI)

$K \quad$ ratio of specific heats

M.W. molecular weight, $\mathrm{kg} / \mathrm{Kmol}$

in mass flow rate, $\mathrm{kg} / \mathrm{sec}$

P pressure, Pa

$P_{a} \quad$ arc power, $W$

$R$ molar gas constant, J/Kmol $K=8315 / M . W$.

$T_{0}$ gas temperature, $K$

$v$ exhaust velocity, $\mathrm{m} / \mathrm{sec}$

$n$ thrust efficiency

$$
\begin{aligned}
& =\frac{\frac{1}{2} m v_{h}^{2}}{P_{a}+\frac{1}{2} m v_{c}^{2}} \\
& =\frac{I_{s p h}^{2}}{\frac{2}{g^{2}} \frac{P_{a}}{m}+I_{s p c}^{2}}
\end{aligned}
$$

16 


\section{REFERENCES}

1. Wallner, L.E.; and Czika, J., Jr.: Arcjet Thrustor for Space Proplision. NASA TN-D-2868, 1965.

2. Todd, J.P.: $30 \mathrm{~kW}$ Arc-Jet Thrustor Research. APL-TDR-64-58, Giarnini Sclentific Corp., Mar. 1964. (AD-601534).

3. John, R.R.: Connors, J.F.; and Bennett, S.: Th1rty-Day Endurance Test of a $30 \mathrm{~kW}$ ARC Jet Engine. ALAA Paper 63-274, June 1963.

4. The Development of an Electrothermal Propulsion System. Report no. PRE-101, Nov. 10, 1961.

5. Kallis, J.M.; Goodman, M.; and Halbach, C.R.: Viscous Effects on Blowaste Resistojet Nozzle Performance. J. Spacecr. Rockets, vol. 9, no. 12 , Dec. 1972.

6. Gruber, R.P.; Private discussions. MASA Lewis Research Center, Cleveland, Ohio.

7. Zafran, S.: and Jackson, B.: Electrothermal Thruster Diagnostics, vol. II: Technical. (TRW-39152-6012-UE-00-VOL-2, TRW, Inc,; NASA Contract NAS3-23265) NASA CR-168174, 1983.

8. Hardy, T.L.: Electrode Erosion in Arc Discharge at Atmospheric Pressure. AIAA Paper 85-2018, Oc士. 1985.

9. Curran, F.M.: An Experimental Study of Energy Loss Mechanisms and Efficiency Considerations in the Low Power D.C. Arcjet. AIAA Paper 85-2017, Oct. 1985.

10. Simmonds, A.L.; Miller, C.G.; and Mealy, J.E.: Tables and Charts of Equilibrium Thermodynamic Properties of Ammonia for Temperatures from 500 to $50,000 \mathrm{~K}$. NASA SP-3099, 1976. 
ORIGINAL PRTE II

OF POOR QUALITY

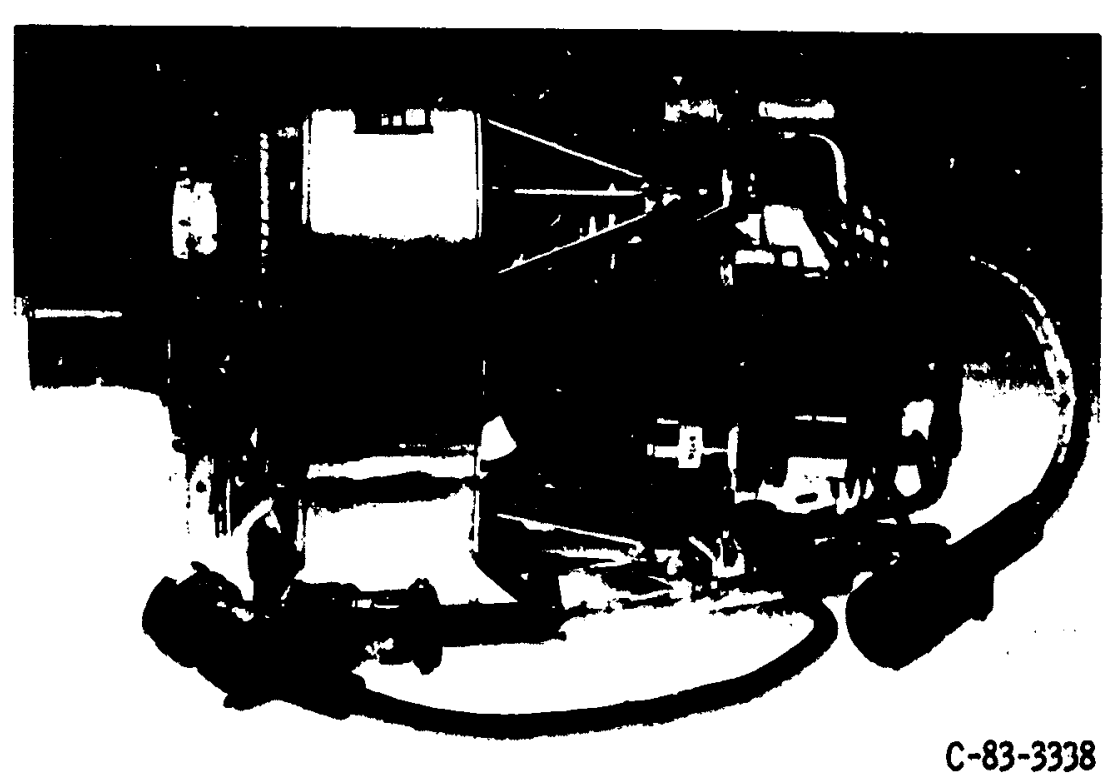

Figure 1. - Plasmadyne $1 \mathrm{~kW}$ arcjet thruster flight system. 


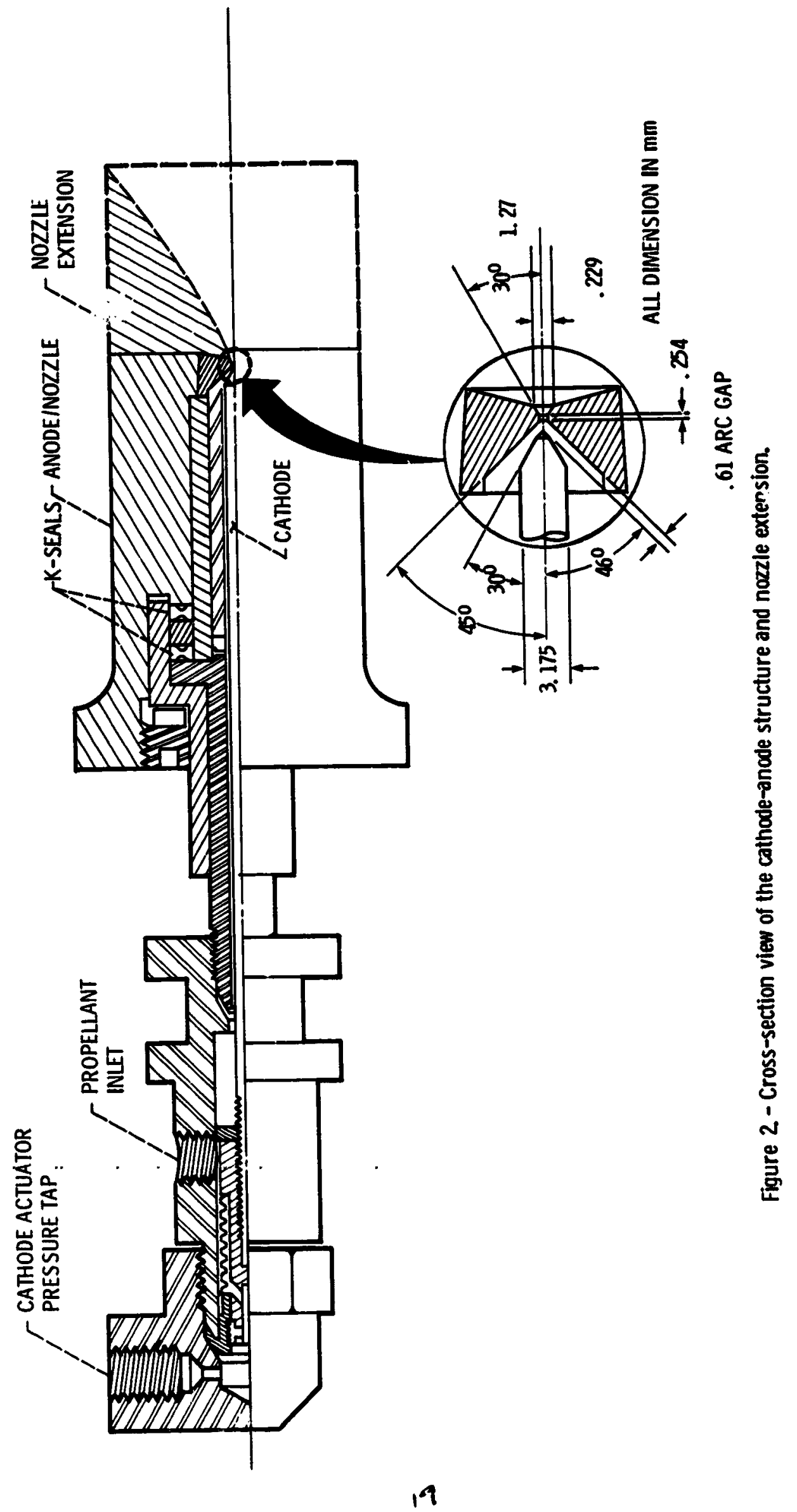




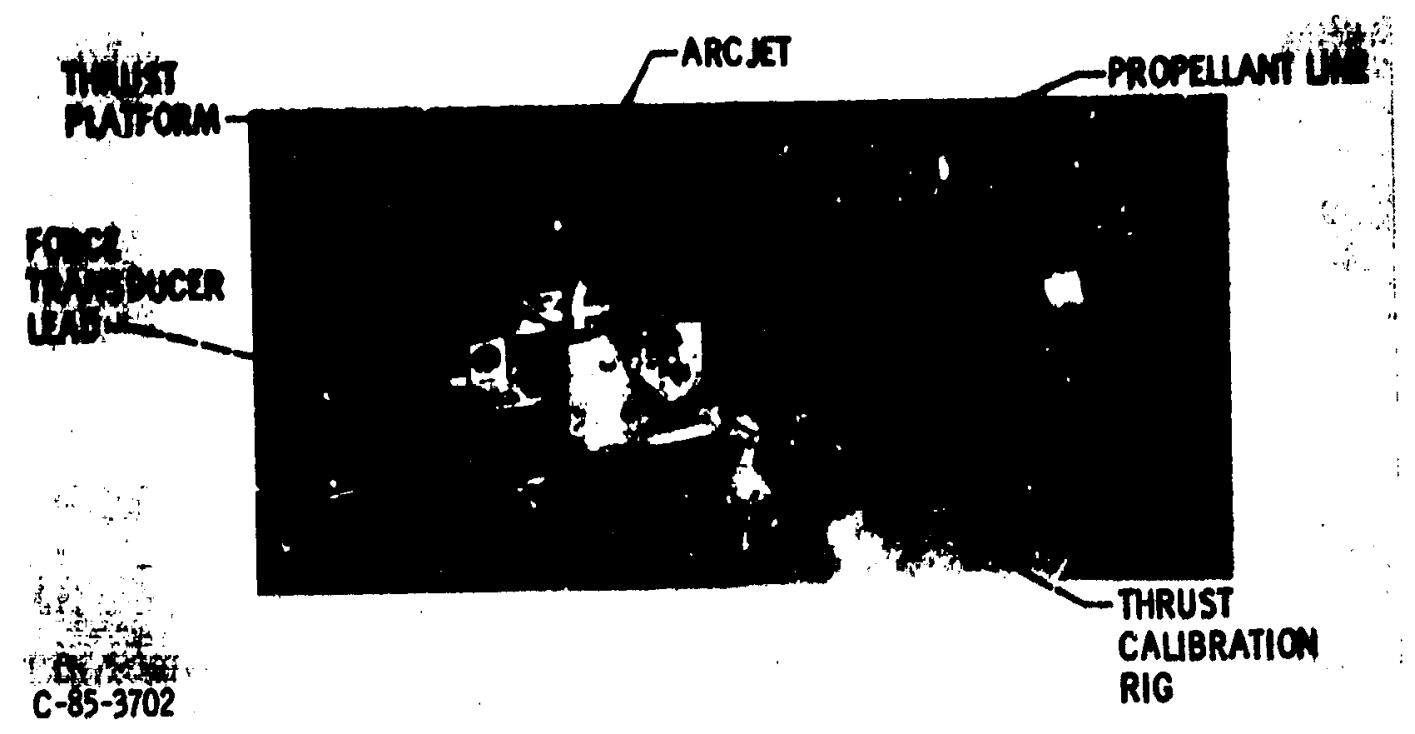

Figure 3. - Arcjet thruster mounted on thrust stand in test chamber.

civenal page is

OF. POOR QuALIT.

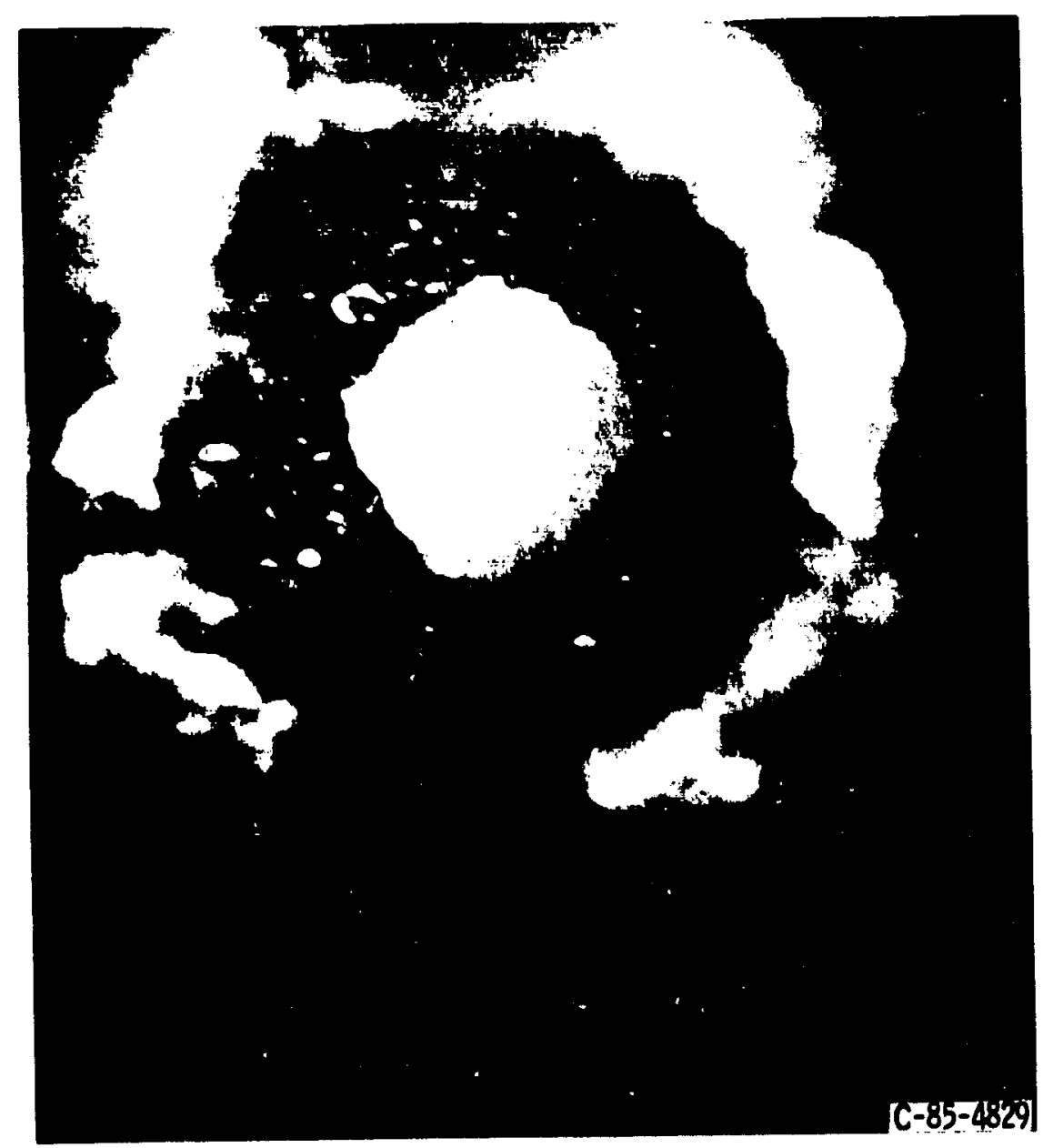

Flgure 4. - Photomicrograph of nozzle throat from diverging side. Scale: 0.001 in and $0.010 \mathrm{in}$. 


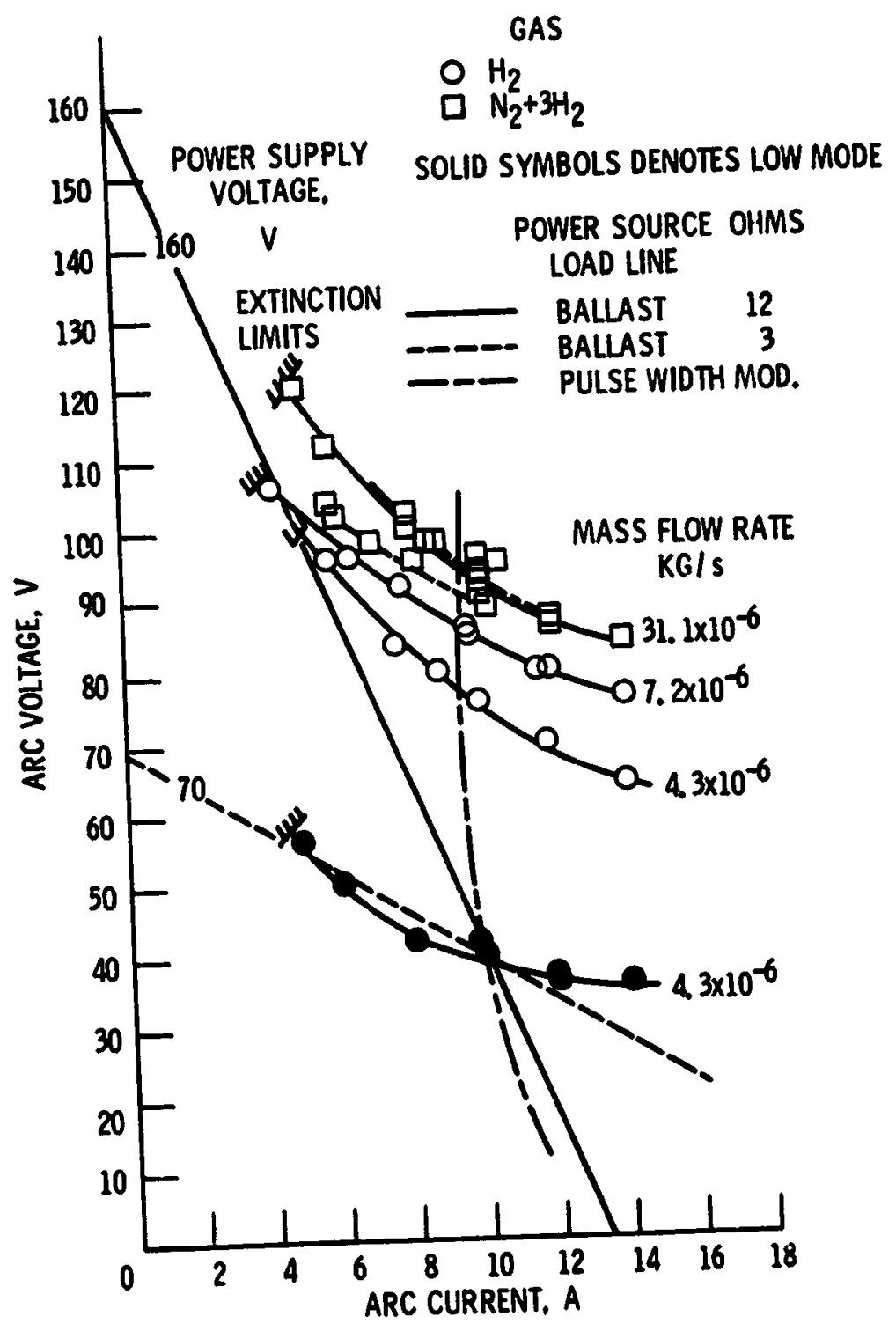

Figure 5. - Voltage - current characteristics of arc jet and power source. 



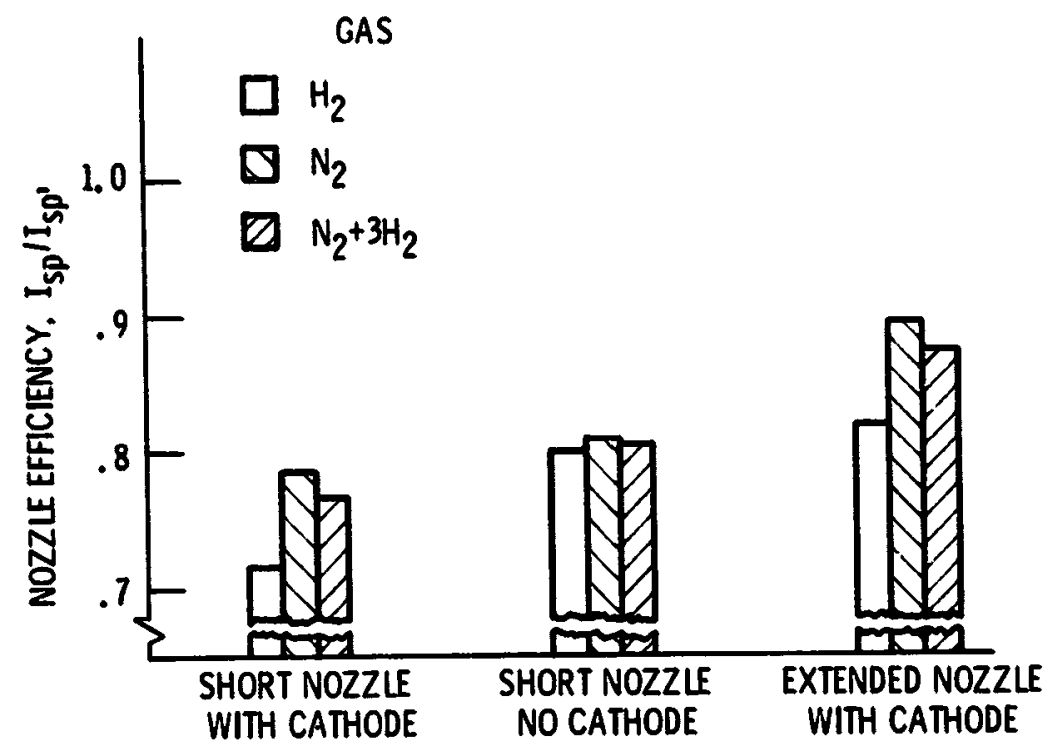

Figure 7. - Cold flow nozzle performance of various configurations and propellants. Gas teriperature, $295^{\circ} \mathrm{K}$. 


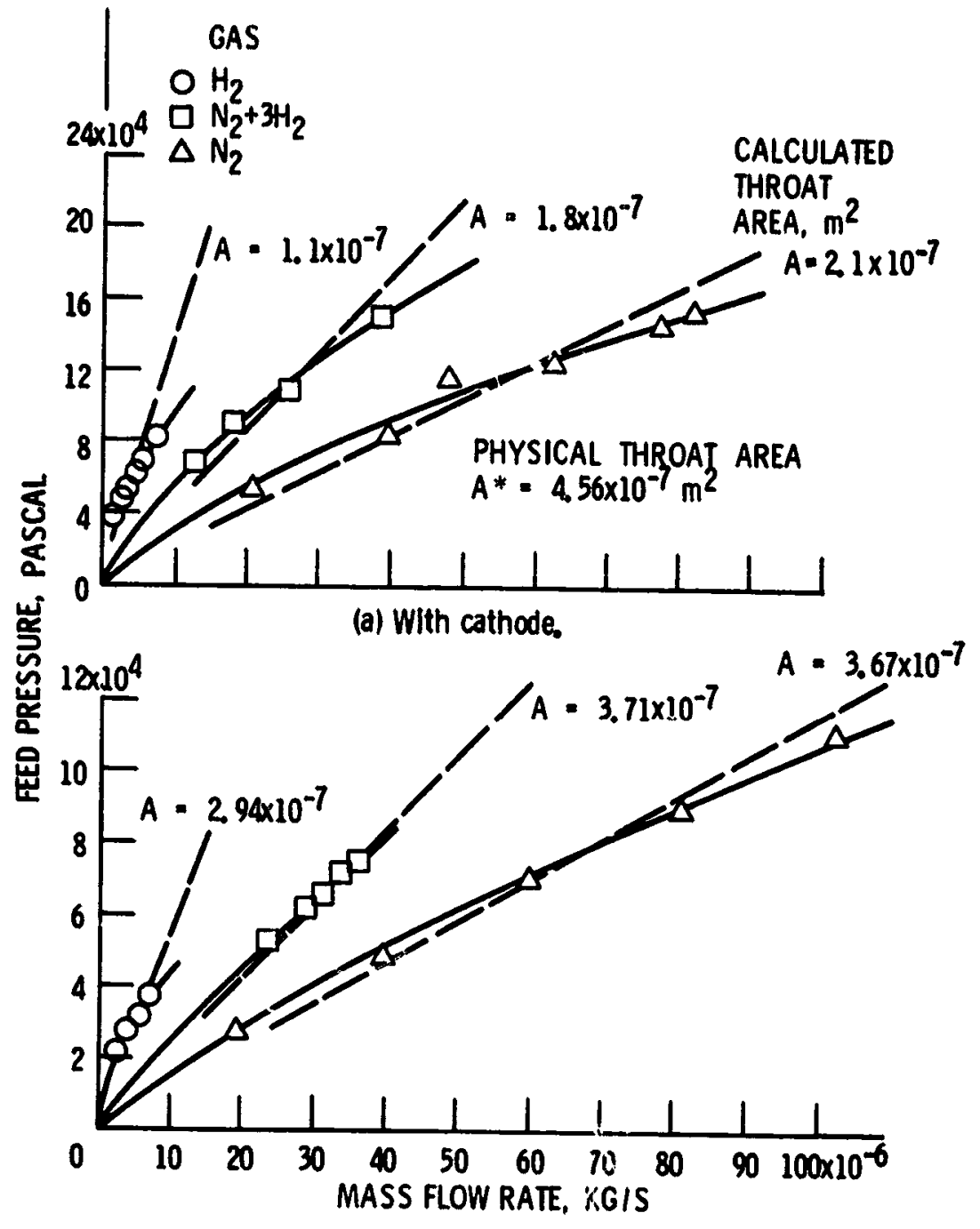

(b) Without cathode.

Figure 8. - Cold flow feed line pressure of the short nozzle configuration. 

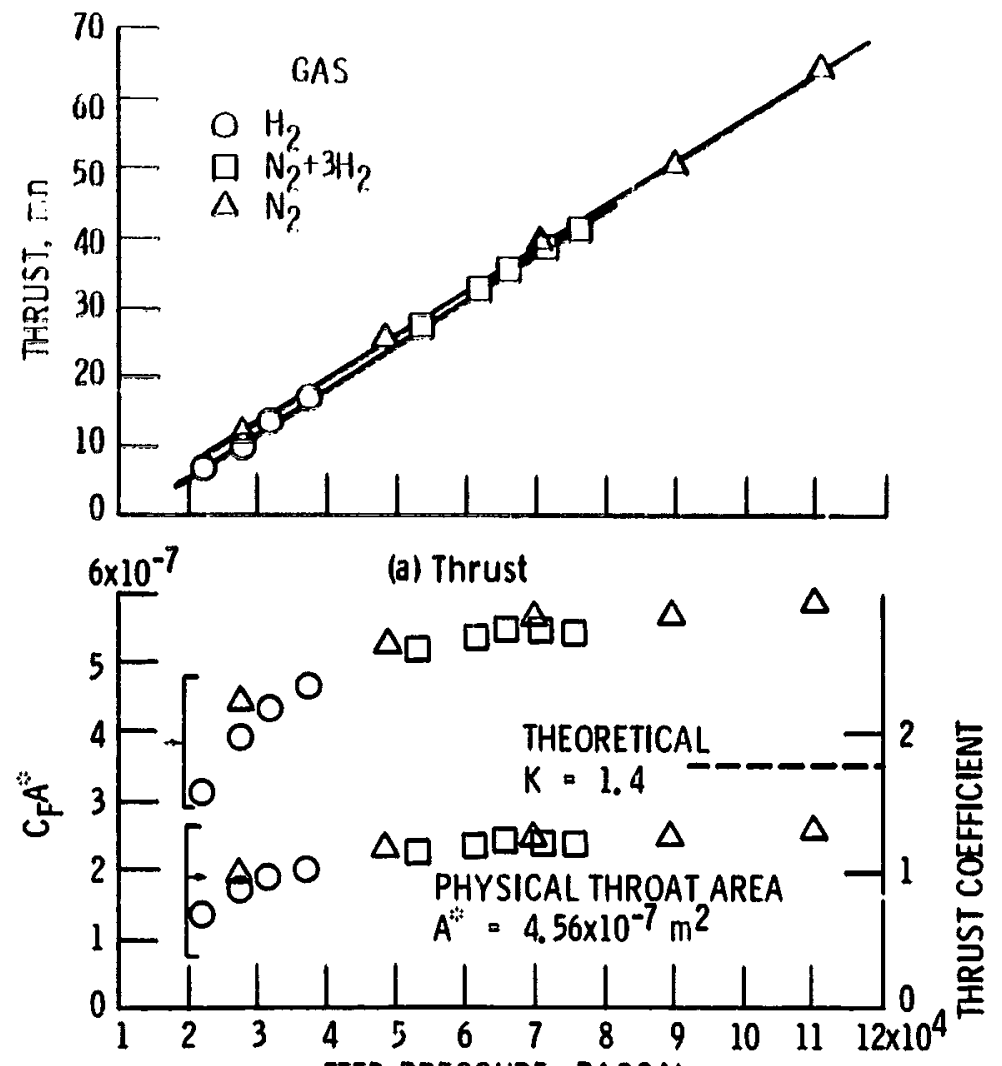

FEED PRESSURE, PASCAL

(b) Nozzle and thrust coefficients.

Figure 9. - Cold flow characteristics of short nozzle configuration without cathode.

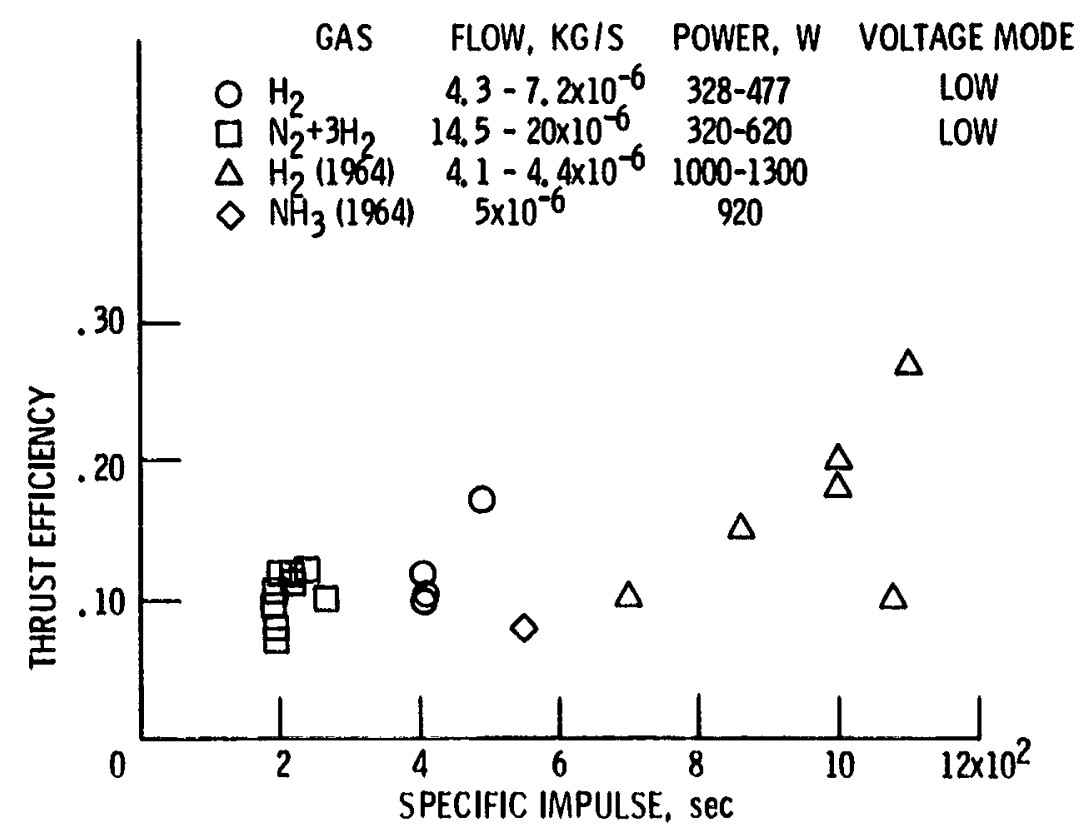

Figure 10. - Performance of short nozzle arc jet. 


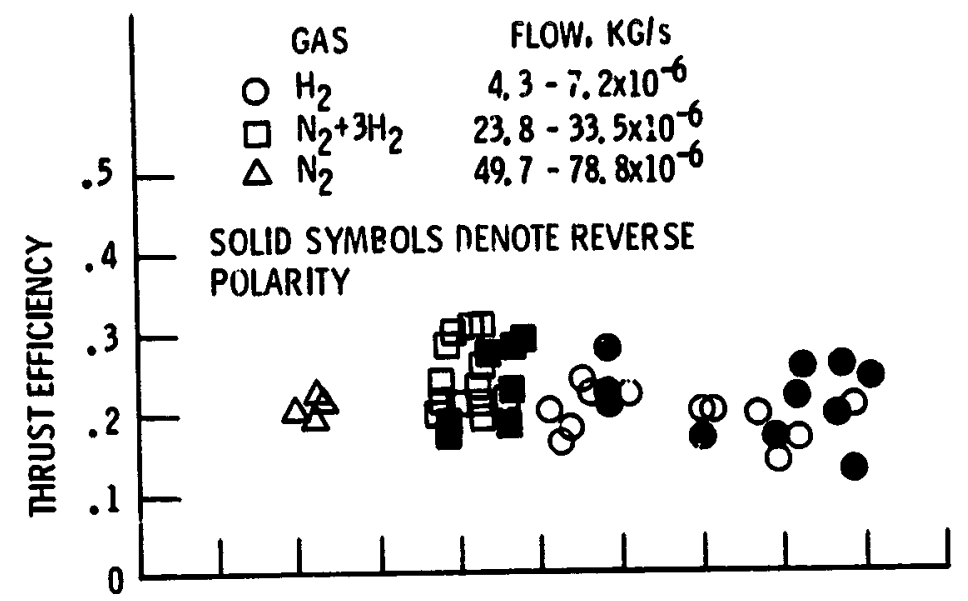

(a) Thrust efficiency.

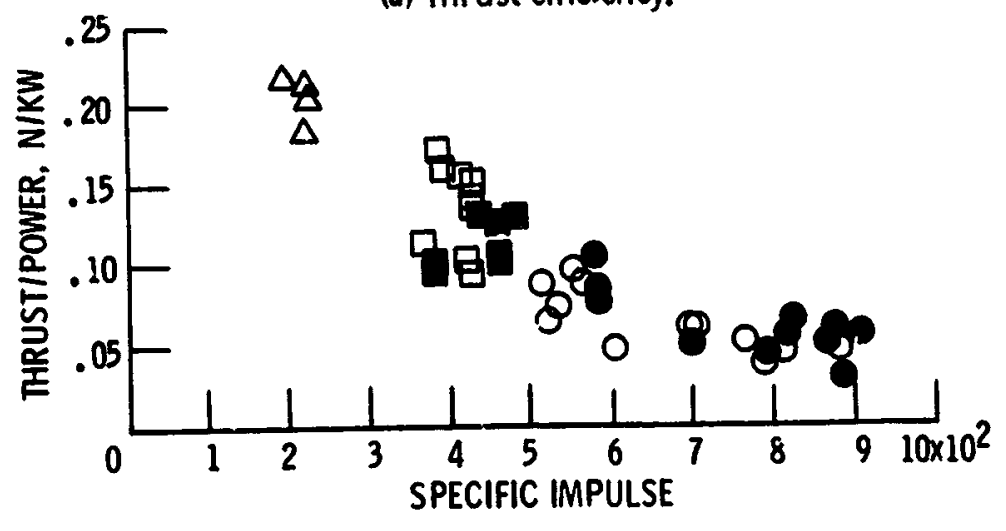

(b) Thrust to power ratio.

Figure 11. - Pirformance of extended nozzle arc jet. 


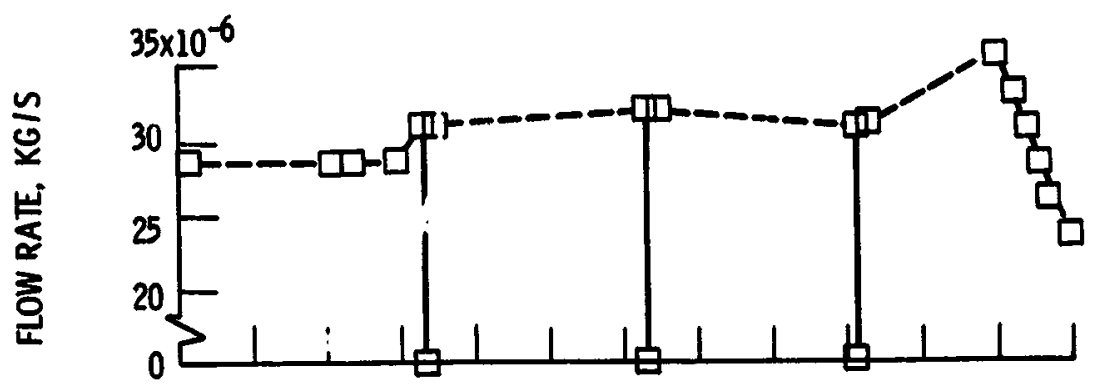

(a) Propellant flow rate.

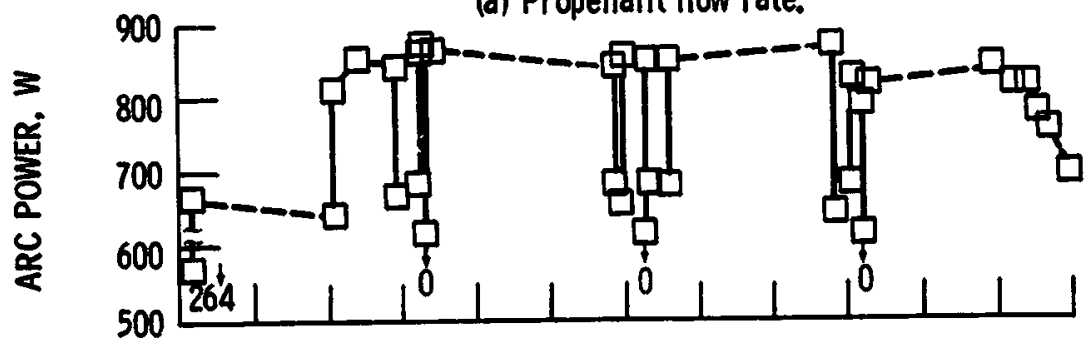

(b) Arc power.
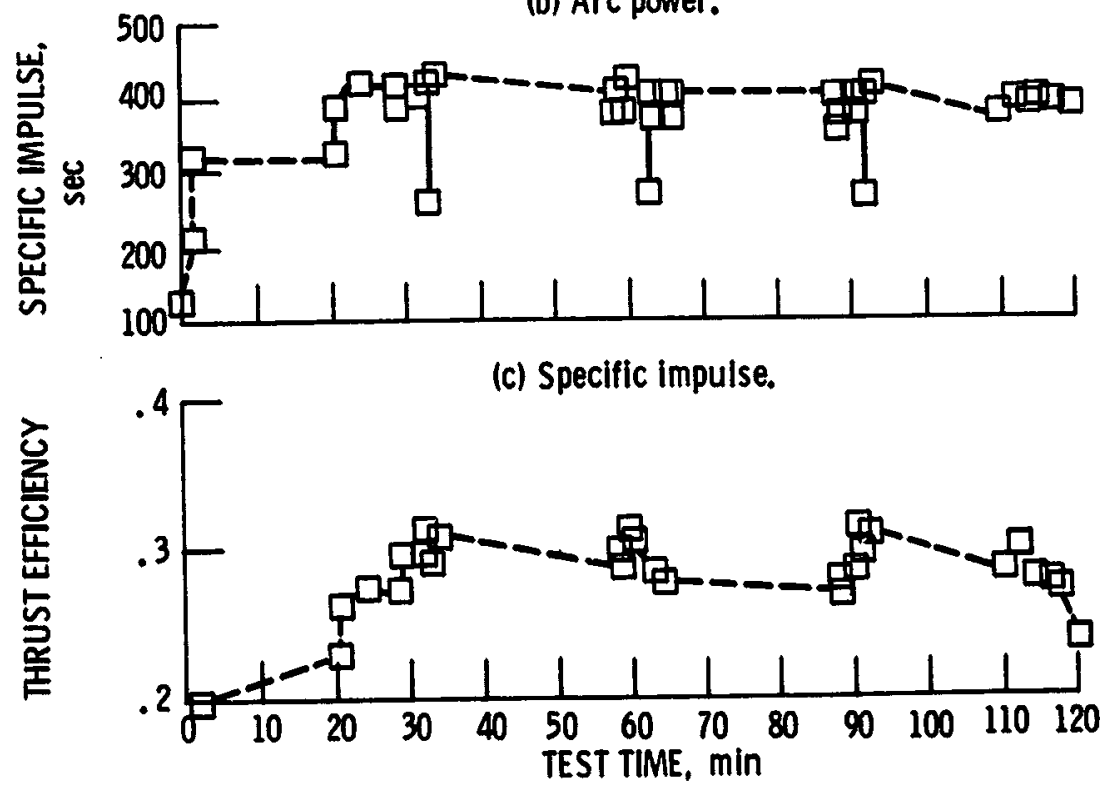

(d) Thrust efficiency.

Figure 12. - Two-hour test of extended nozzle thruster using modulated power source. Propellant, $\mathrm{N}_{2}+3 \mathrm{H}_{2}$; arc current, $8-10 A$. 


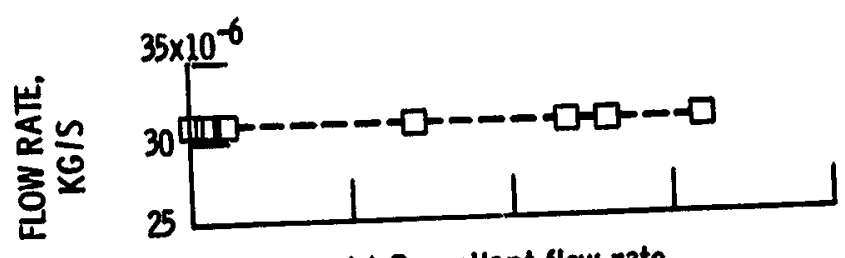

(a) Propellant flow rate.

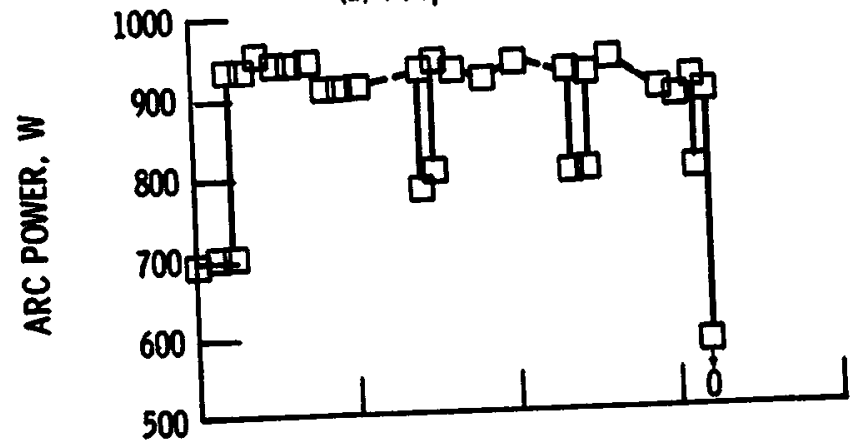

(b) Arc power.
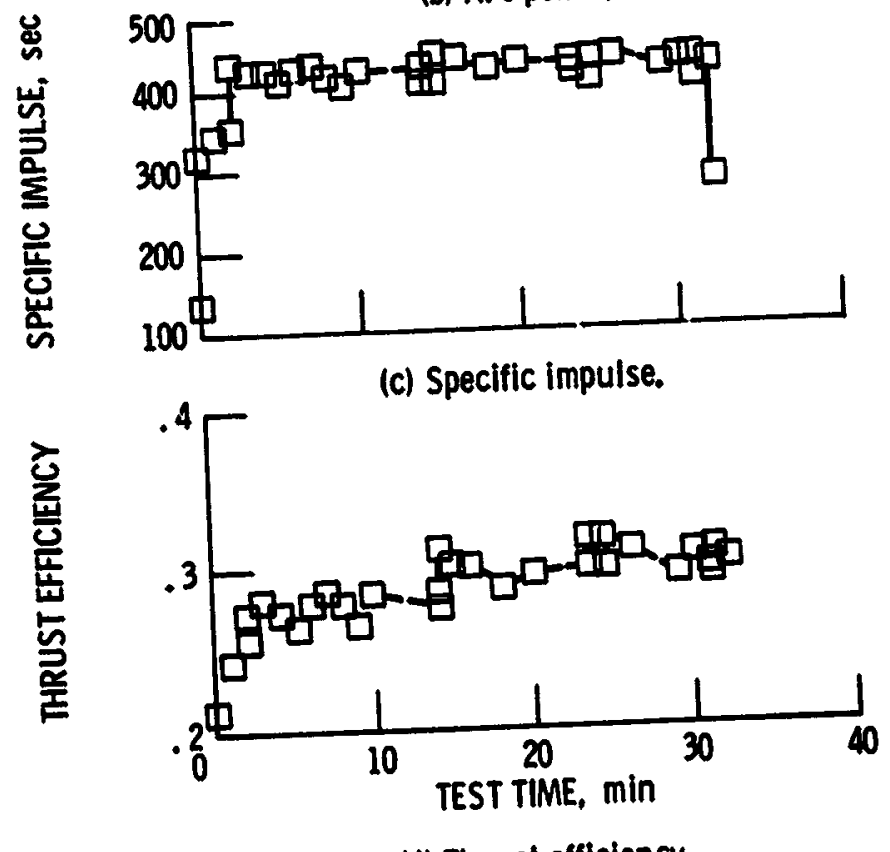

(d) Thrust efficiency.

Figure 13. - Typical start sequence and short test of extended nozzle thruster using modulated power source. Propellant, $\mathrm{H}_{2}+\mathrm{H}_{2}$; arc current, $10 \mathrm{~A}$. 


\begin{tabular}{|c|c|c|}
\hline $\begin{array}{l}\text { 1. Report No. } \\
\text { NASA TM-87131 }\end{array}$ & 2. Government Accession Ho. & 3. Recipient's Catalog No. \\
\hline \multirow{3}{*}{\multicolumn{2}{|c|}{$\begin{array}{l}\text { Experimenta } 1 \text { Performance of a l-K1lowatt Arcjet } \\
\text { Thruster }\end{array}$}} & 6. Report Date \\
\hline & & \\
\hline & & $506-55-22$ \\
\hline \multirow{3}{*}{\multicolumn{2}{|c|}{$\begin{array}{l}\text { 7. Author(o) } \\
\text { Shigeo Nakan!sh1 }\end{array}$}} & 8. Purforming Organization Report No. \\
\hline & & $E-2744$ \\
\hline & & 10. Work Unit No. \\
\hline \multirow{3}{*}{\multicolumn{2}{|c|}{$\begin{array}{l}\text { 9. Performing Organization Name and Address } \\
\text { National Aeronautics and Space Administration } \\
\text { Lewis Research Center } \\
\text { Cleveland, Ohio } 44135\end{array}$}} & 11. Contiact or Grant No. \\
\hline & & \\
\hline & & 13. Type of Report and Perlod Coverod \\
\hline \multicolumn{2}{|c|}{ 12. Sponsoring Agency Name and Address } & Technical Memorandum \\
\hline \multicolumn{2}{|c|}{$\begin{array}{l}\text { National Aeronautics and Space Administration } \\
\text { Washington, D.C. } 20546\end{array}$} & 14. Sponsoring Agency Code \\
\hline \multirow{2}{*}{\multicolumn{3}{|c|}{$\begin{array}{l}\text { 15. Supplementary Not: } \\
\text { Prepared for the 18th International Electric Propulsion Conference, cosponsored } \\
\text { by the AIAA, DGLR, and JSASS, Alexandr1a, VIrginla, September. 30-0ctober 2, } 1985 \text {. }\end{array}$}} \\
\hline & & \\
\hline \multicolumn{3}{|c|}{ 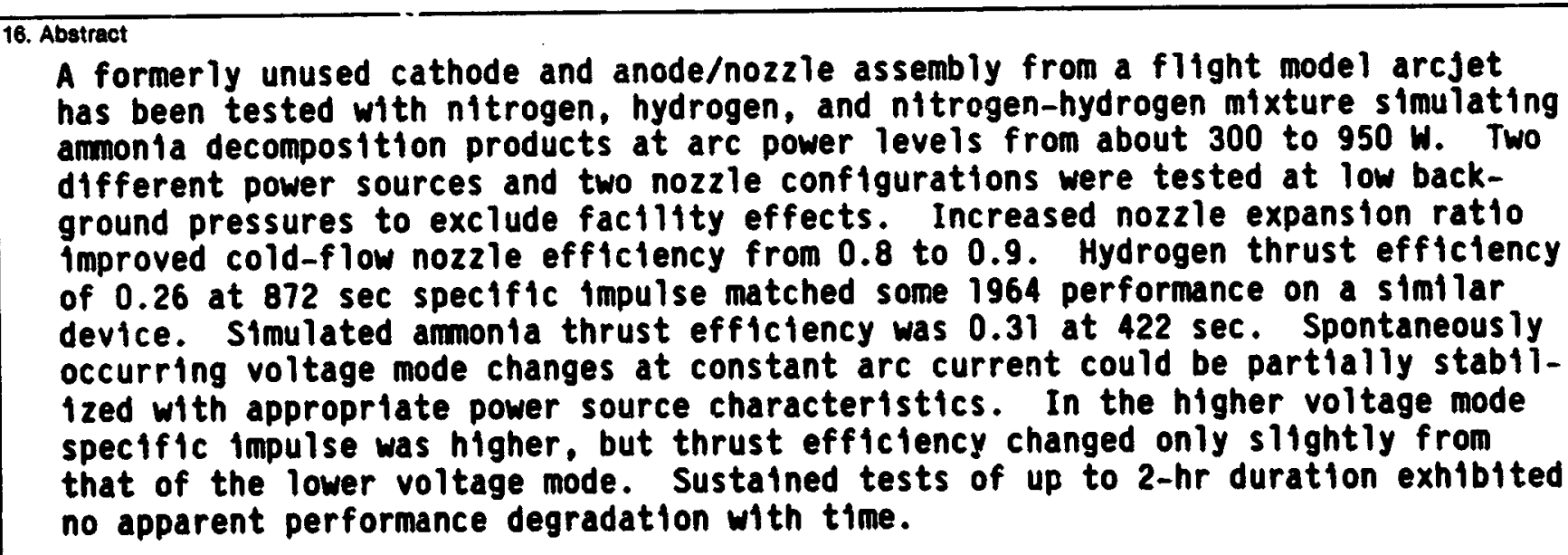 } \\
\hline \multicolumn{2}{|l|}{ 17. Koy Words (Suggested by Author(s)) } & 18. Dietribution Statement \\
\hline \multicolumn{2}{|c|}{ Electric propulsion; Arcjet } & $\begin{array}{l}\text { Unclassifled - unlimited } \\
\text { STAR Category } 20\end{array}$ \\
\hline $\begin{array}{r}\text { 18. Socurlty Classlf. (of this report) } \\
\text { Unc lass if fed }\end{array}$ & $\begin{array}{l}\text { 20. Security Clessili. (of this page) } \\
\text { Unc lass if I ed }\end{array}$ & 21. No. of pages \\
\hline
\end{tabular}

"For sale by the National Technical Information Service, Springfleld, Virginla 22161 